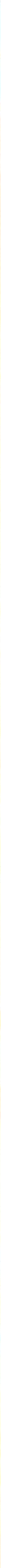

-

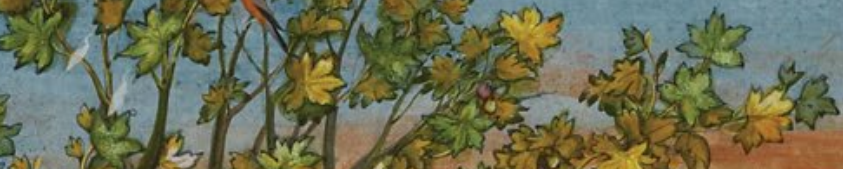

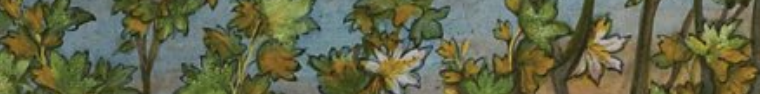


TELLINGS AND TEXTS 



\section{Tellings and Texts}

\section{Music, Literature and Performance in North India}

Edited by Francesca Orsini and Katherine Butler Schofield 


\section{http:/ / www.openbookpublishers.com}

(C) Francesca Orsini and Katherine Butler Schofield. Copyright of individual chapters is maintained by the chapters' authors.

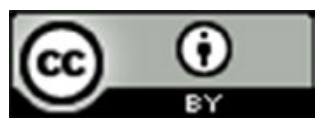

This work is licensed under a Creative Commons Attribution 4.0 International license (CC BY 4.0). This license allows you to share, copy, distribute and transmit the work; to adapt the work and to make commercial use of the work providing attribution is made to the author (but not in any way that suggests that they endorse you or your use of the work). Attribution should include the following information:

Orsini, Francesca and Butler Schofield, Katherine (eds.), Tellings and Texts: Music, Literature and Performance in North India. Cambridge, UK: Open Book Publishers, 2015. http://dx.doi.org/10.11647/OBP.0062

Further details about CC BY licenses are available at http:/ / creativecommons.org/ licenses/by/4.0/

In order to access detailed and updated information on the license, please visit: http://www.openbookpublishers.com/isbn/9781783741021\#copyright

All external links were active on 22/09/2015 and archived via the Internet Archive Wayback Machine: https://archive.org/web/

Digital material and resources associated with this volume are available at http:/ / www.openbookpublishers.com/isbn/9781783741021\#resources

ISBN Paperback: 978-1-78374-102-1

ISBN Hardback: 978-1-78374-103-8

ISBN Digital (PDF): 978-1-78374-104-5

ISBN Digital ebook (epub): 978-1-78374-105-2

ISBN Digital ebook (mobi): 9978-1-78374-106-9

DOI: $10.11647 /$ OBP.0062

King's College London has generously contributed to the publication of this volume.

Cover image: Late eighteenth-century miniature by Mir Kalan Khan (Awadh, c.1775). Photo by Pernille Klemp. () The David Collection, Copenhagen. Inventory no. 50/1981. All rights reserved.

Cover design by Heidi Coburn.

All paper used by Open Book Publishers is SFI (Sustainable Forestry Initiative) and PEFC (Programme for the Endorsement of Forest Certification Schemes) Certified.

Printed in the United Kingdom and United States by Lightning Source for Open Book Publishers 
To Aditya's memory, once again 



\section{Contents}

Acknowledgements ix

Note on Transliteration $\quad$ xi

Note on Dating Systems xii

List of Illustrations xiii

Notes on Contributors $\quad$ xv

Introduction 1

Francesca Orsini and Katherine Butler Schofield

I. Between Texts and Practices

1. The Example in Dadupanthi Homiletics 31 Monika Horstmann

2. Making it Vernacular in Agra: The Practice of Translation by Seventeenth-Century Jains John E. Cort

3. World Enough and Time: Religious Strategy and Historical Imagination in an Indian Sufi Tale Muzaffar Alam

4. Hearing Mo'jizat in South Asian Shi'ism Amy Bard

\section{Books and Performances, Books for Performance}

5. Note to Self: What Marathi Kirtankars' Notebooks Suggest about Literacy, Performance, and the Travelling Performer in Pre-Colonial Maharashtra

Christian Lee Novetzke

6. A Handbook for Storytellers: The Tirāz al-akhbār and the Qissa Genre

Pasha M. Khan 
7. Did Surdas Perform the Bhāgavata-purāna? John Stratton Hawley

8. Text, Orality, and Performance in Newar Devotional Music 231 Richard Widdess

\section{Written Clues about Performed Texts}

9. Listening for the Context: Tuning in to the Reception of Riti Poetry Allison Busch

10. Reading the Acts and Lives of Performers in Mughal Persian Texts

Sunil Sharma

11. Persian Poets on the Streets: The Lore of Indo-Persian Poetic Circles in Late Mughal India Stefano Pellò

12. Texts and Tellings: Kathas in the Fifteenth and Sixteenth Centuries Francesca Orsini

13. A Curious King, a Psychic Leper, and the Workings of Karma: Bajid's Entertaining Narratives

Imre Bangha

\section{Musical Knowledge and Aesthetics}

14. Raga in the Early Sixteenth Century Allyn Miner

15. Learning to Taste the Emotions: The Mughal Rasika 407 Katherine Butler Schofield

16. Patterns of Composition in the Seventeenth-Century Bengali Literature of Arakan Thibaut d'Hubert

17. The Musical Lives of Texts: Rhythms and Communal Relationships among the Nizamis and Some of Their Neighbours in South and West Asia

Richard K. Wolf

Glossary 


\title{
11. Persian Poets on the Streets: The Lore of Indo-Persian Poetic Circles in Late Mughal India
}

\author{
Stefano Pellò
}

\section{Memorialising the Present}

The early modern Persian tazkira can be thought of as an attempt to catalogue and archive, in a narrative-fictional way, specific individual personalities and the internal dynamics of the Persian-writing poetic community, and thus to describe (in terms that are also prescriptive) its protocols with regards to poetic education, poetic production, reception, and criticism. In other words, the genre of literary tazkiras can be understood as a kind of autobiography or, even better, auto-hagiography of Persian literature by its own protagonists. "Hagiography" can then

1 In Persian the genre of poetic tazkiras is closely related to that of sufi tazkiras, and they benefit from much the same conceptual and methodological tools, from protocols to expressive codes; see M.K. Hermansen, 'Religious Literature and the Inscription of Identity: The Sufi Tazkira Tradition in Muslim South Asia', The Muslim World 87. 3/4 (JulOct 1997): 315-20. But Persianate poetic tazkiras do not just inscribe a "Muslim identity" (Hermansen: 317), they tend to canonise multiple and co-existing identities first of all by recalling, through a shared code of expression, a shared code of social and linguistic practices. The comparison pays off also in the case of saints' and artists' hagiographies in Europe such as Legenda Aurea, the famous thirteenth-century Latin collection of lives of saints by Jacobus de Voragine, and the even more celebrated sixteenth-century collection of lives of Italian Renaissance artists, Giorgio Vasari's Le vite de' più eccellenti pittori, scultori, ed architettori, ed. by G. Milanesi (Florence: Sansoni, 1880). 
be read here as the institutionalisation of reference figures, a powerful device for modelling lives within an established and prescriptive palimpsest of poetic/suficate language. ${ }^{2}$

Among other things, Persian poetic tazkiras reflect the ideas that literati had of the occasions and spaces of poetic experience and exchange, and of boundaries governing them-itself one of the pivotal forms of knowledge of the Persianate world. Using the expressive code of poetry itself, the tazkira genre explores, catalogues, and gives rhetorical form to the pre-textual and the con-textual dimensions of poetry both as a meaningful social craft and a powerful way of controlling and exploiting the langue of the Persianate cosmopolis. What do I mean by this? As a whole, Persian tazkiras are very much concerned with an ideology of harmonic continuity and the textual recreation of a dia-chronic and dia-topic, or even u-chronic and u-topic, majlis ("assembly") of poets, who often belonged to different chronological and geographical backgrounds, as the titles themselves indicate. ${ }^{3}$ After all, as a verbal-noun deriving from the Arabic root ZKR, "to remember, to recall", the word tazkira itself declares the primary concern of this wide, multi-purpose, or rather "container-genre" to be the memory of a past, in our particular case the memory of the literary past. ${ }^{4}$ More

2 For an example of the (self-) inscription of the Vaishnava disciples of Bedil's poetic circles that used this poetic/suficate language, see Stefano Pellò, 'Persian as a PassePartout: The Case of Mirza 'Abd al-Qadir Bedil and his Hindu Disciples', in Culture and Circulation: Literature in Motion in Early Modern India, ed. by Thomas de Brujin and Allison Busch (Leiden: Brill, 2014), pp. 21-46.

3 Titles signify the shared imaginary textual space-time in which poetic/sufi individual personalities are located and re-located through reference not only to places (including the all-embracing Haft iqlimm, "Seven climes") but to other generic collective spaces, such as the majlis "assembly", the rawza "garden", the safina "ship", etc: in Ahmad Gulchin-i Ma'ani's survey on Persian tazkiras we meet, for instance, six majlises (or the plural form majalis), fourteen rawzas (or the plural form riyaz), nine safinas, as well as several other loci of the lyrical langue related to the poetic space of the "garden", such as hadiqas, gulzars, gulistans, gulshans, baharistans, baghs; maykhanas, maykadas, kharabats (the canonical taverns), atashkhanas (the antinomistic fire-temple), nigaristans (the pictorial gallery of beauties), etc., all before the beginning of the fourteenth century of the Hijra; Ahmad Gulchin-i Ma'ani, Tārīkh-i tazzkirahāa-yi Fārsī, 2 vols (Tehran: Intisharat-i Danishgah-i Tihran, 1348-1350/1969-1971).

4 As Marcia K. Hermansen and Bruce B. Lawrence state, "tazkiras, as their name suggests, both memorialise individuals and communicate their legacy to a new generation [...] If there is a word for understanding poetic and sufi tazkiras, it is memory"; M.K. Hermansen and B.B. Lawrence, "Indo-Persian Tazkiras as Memorative Communications", in Beyond Turk and Hindu: Rethinking Religious Identities in Islamicate South Asia, ed. by D. Gilmartin and B.B. Lawrence (Gainesville, FL: University Press of Florida, 2000), pp. 149-75, p. 152. 
specifically, literary tazkiras operate as interrelated fragments of a genre both in compilative and (re-)creative continuity, working at the same time as commentaries (sharh) and lexicons (farhang) of the Persianate literary community. They preserve and adapt a code while codifying and adapting the memory of individual personalities. ${ }^{5}$ Yet, predictably enough, the way in which writers framed this concern changed over time and space. The great Timurid and post-Timurid tazkiras (from the Tazkirat al-shu'arā by Dawlatshah Samarqandi onwards), for instance, appear to be primarily interested in shaping a durable canon, comparing the great masters of the past to the main poets of the present, and connecting the texts produced by the latter to the models of the former. ${ }^{6}$ But from the end of the seventeenth century onward in North India, we witness instead a growing interest in shaping the idea of the present. In other words, the focus shifts from the relationship between modern poets (the muta'akhkhirān) and the classics (mutaqaddimān), to the relationship of modern poets with one another: from a memory of the distant past to a memory of the closer and more familiar past, or of the present. Thus, beside providing biographical information and verse selections, these texts communicate the varied and shifting behaviour, tastes, sensibilities, hermeneutic tools, and approaches that the interrelated and ever-expanding Persian-writing literary communities of the wider Persianate world used.

This centrality of the present as a theme to be studied in and for itself, and a related feeling of the newness of doing so, can be found in the introduction of a tazkira completed in Delhi in 1682, the Kalimāt al-shu'arā by Muhammad Afzal Sarkhush. The author specifies that:

before this, the venerable people who decided to devote themselves to writing and composing poetic tazkiras used to start from the life and the

5 Just as Hafiz in the opening ghazal of his diwan retraces, according to Julie Scott Meisami, "a life in, and of, poetry-his own poetry, and that of the traditions that inform it"; J.S. Meisami, 'A Life in Poetry: Hafiz's First Ghazal', in The Necklace of the Pleiades: 24 Essays on Persian Literature, Culture and Religion, ed. by F.D. Lewis and S. Sharma (Leiden: Leiden University Press, 2010), pp. 163-81, p. 172.

6 See Paul E. Losensky, Welcoming Fighanni: Imitation and Poetic Individuality in the Safavid-Mughal Ghazal (Costa Mesa: Mazda, 1998), ch. 4. On the fecund centrality of the relationship with the past in the Timurid poetic milieu see also Riccardo Zipoli, The Technique of the Ğawāb: Replies by Nawa'̄' to Hā fiz and Ğām $\bar{\imath}$ (Venice: Cafoscarina, 1993), and Marta Simidchieva, 'Imitation and Innovation in Timurid Poetics: Kāshifi's Badāyi' al-afkār and its Predecessors, al-Mu'jam and Hadā'iq al-sihr', Iranian Studies 36.4 (2003), 509-30. 
poetry of Hakim Rudaki and to arrive to the authors of their own age. As for the people who lived up to and including the age of Emperor Akbar, their memory can be found in every historical writing and in every tazkira. The present writer now feels that there is little merit in going on copying from the works of each other and repeating things. [...] Since the present age is full of writers who know how to deal with many-coloured images and fresh new concepts, it will not be inopportune to devote oneself to describe their lives and to speak about the peculiarities of their poetical discourse. $^{7}$

The reference to "many-coloured images and fresh new concepts" evokes the coeval spread of the concepts of newness in writing poetry, variously called tarz-e naw, tāzagūyi, and so on. For our purposes here, it is tempting to connect this explicit historical consciousness and programmatic declaration to the emergence of urban poetic circles (called maktabs, lit. "schools"), sometimes based in the houses of the most eminent masters, as sites of poetic production in late-seventeenth-century, and especially eighteenth-century, Delhi and North India in general. These new semipublic spaces and dynamics, such as the "bourgeois" musha'ira or the institutionalisation of the master-disciple (ustad-shagird) relationship, needed a form to be textualised in while Persian increased its social and ideological reach as the language of choice for a widening class of secretaries and scribes who "took their work home" and needed to find a place for themselves in the sociotextual sphere of Persian literary culture. ${ }^{8}$ (It is not by chance that we find several Kayasths and Khatris among the tazkira-writers of the period.) "In the musha'irah", Jamal Malik reminds us,

it was not only "a middle class who was interested in Persian and Urdu poetry and among whom one could count representatives of military, administration, as well as notables and traders" that participated. These public spaces also provided a gregarious forum for communications and the perennial co-option of new members from the lower classes, including barbers, soldiers, perfume vendors, masons, weavers, tailors and

7 Muhammad Afzal Sarkhwush, Kalīmāt al-shu'arā, ed. by M. H. Mahvi Lakhnawi (Madras: [s.n.], 1951), pp. 2-3.

8 I borrow the term from Sheldon Pollock, who defines the "sociotextual community" as "the community for which literature is produced, in which it circulates, and which derives a portion of its self-understanding as a community from the very act of hearing, reading, performing, reproducing, and circulating literary texts"; S. Pollock, 'Introduction', Literary Cultures in History: Reconstructions from South Asia, ed. by S. Pollock (Berkeley: University of California Press, 2003), p. 27. 
carpenters, presupposed permanent social openness [...] And precisely because of the heterogeneous status and the intellectual heterogeneity of the participants, these fora of exchange and expression, which also contributed to the processes of consensus forming and group building, gave rise to a new trend in taste and the formation of a moral institution alternative to the court. ${ }^{9}$

Thus both the space of the urban poetic circle, the non-courtly musha'ira, and the master-disciple relationship came actively into play in the creation of new literary identities in the Persian (and increasingly Urdu) context. ${ }^{10}$ A model for the new type of Indo-Persian poetic circle was the maktab or circle of Mirza Bedil in Delhi, about whom Lachhmi Narayan Shafiq writes, in the introduction of his tazkira Gul-i ra'nāa, that:

in the days of Shah 'Alam, Muhammad Farrukhsiyar and Muhammad Shah, thanks to the graceful company of Mirza Bedil-mercy be upon him-many individuals from the people of the Hindus acquired the talent of weighing poetic expressions. And so the Indian parrots tasted a new sugar, as will become clear from the reading of the subsequent pages. ${ }^{11}$

For the purpose of this volume, the questions that we need to ask are: what oral practices flowed into these "new" Persian circles? And conversely, what role did these circles play in producing a particular kind of oral culture, glimpses of which we glean from reading tazkira literature? Tazkiras were for a long time decried as devoid of "any consistent principle of selectivity, critical evaluation of facts, or analytical framework" and "resistant to critical theory because they are drenched in the minutiae of local detail". ${ }^{12}$ Yet precisely these supposed limits of tazkiras are providential when we want to explore the closeness of these texts to the domain of their pre-textual orality, a shared set of

9 J. Malik, 'Muslim Culture and Reform in 18th Century South Asia', Journal of the Royal Asiatic Society 13.2 (2003), 227-43, p. 240, quoting Ali Jawad Zaidi, Tārīkh-i mushā'ira (Delhi: [n.p.], 1989), p. 109.

10 See Pellò, 'Persian as a Passe-Partout', passim. The usefulness of focusing on poetic apprenticeship in eighteenth-century North India, and especially Delhi, was noticed by C.M. Naim ('Poet-Audience Interaction at Urdu Musha'iras', in Urdu and Muslim South Asia: Studies in Honour of Ralph Russell, ed. by C. Shackle (Delhi: Oxford University Press, 1991), pp. 167-73, p. 173; a more sustained study of master-disciple relationships in the burgeoning Urdu poetic culture is Frances Pritchett, 'A Long History of Urdu Literary Culture, Part 2', in Literary Cultures in History: Reconstructions from South Asia, ed. by S. Pollock, pp. 864-911.

11 Lacchmi Narayan Shafiq, Tazkkira-yi gul-i ra'nā (Hyderabad: 'Ahd Afarin Barqi Press, [n.d.]), p. 2.

12 Ibid. 
stories with several variants. Tazkiras textualise, so to speak, the open canovaccios of the fragmented narratives of Persian literature. The "minutiae of local detail" in particular guide us to the question of how the "local" was made cosmopolitan, and how the ideals of canonical persistence were localised in a context-that of late-seventeenth- and eighteenth-century Indo-Persian literary culture-where we witness an ever-growing interest for the non-Persian and for the previously extracanonical South Asian spaces, subjects, narratives, and texts..$^{13}$ In short, if properly analysed tazkiras can provide modern readers with insights into the con-textual and pre-textual dimensions of late-Mughal Persian poetry.

How to recover and configure the oral dimension ("tellings") in and around tazkira texts is the particular analytical path this chapter seeks to chart. To do so, it concentrates on the web of gossip within IndoPersian maktabs or poetic circles and on their strategies of localisation (the "minutiae of local details"). Besides the already mentioned Kalimāt al-shu'arā by the Delhi-based sufi Mirza Afzal Sarkhush (completed in Delhi in 1682, it contains the biographies of 169 poets), my analysis will largely be based on the third volume of the Safina-yi Khwushg $\bar{u}$ by the Bais Rajput Bindraban Das Khwushgu (completed in Delhi in the mideighteenth century, it contains 245 biographical notices), and the Safina-yi Hind $\bar{\imath}$ by the Kayasth Bhagvan Das Hindi (completed in Lucknow at the very beginning of the nineteenth century, it deals with 335 authors of Persian verse). These last two tazkiras are particularly useful given their explicit interest in charting the contemporary world of Persian poetic production and its "new" subjects adumbrated above, their interest in prominent Indo-Persian maktabs such as that of Mirza Bedil, and their coverage of almost the whole late Mughal period, from the latter part of Aurangzeb's reign to the emergence of Lucknow as a literary centre.

13 I think, for instance, of relatively well-known eighteenth-century works relating to South Asian forms of knowledge such as the Ghizlān al-Hind by Ali Azad Bilgrami (see Sunil Sharma, 'Translating Gender: Āzād Bilgrāmī on the Poetics of the Love Lyric and Cultural Synthesis', The Translator 15.1 (2009), 87-103), but also of the substantial amount of Persian masnavi renderings of Sanskritic literature produced for local patrons in the "new" urban settings, described above well after Dara Shukoh's times and just before the colonial period, still to be explored. The Jilwa-yi zāt by Bedil's disciple Amanat Ray Lalpuri, a long free rendering of the tenth Book of the Bhägavatapurāna in the shape of a Persian masnavi, completed in 1733 for Nawab Amjad Khan (Muhammad Shah's foster brother), is only one among many possible examples; see Pellò, 'Persian as a Passe-Partout'. 


\section{Institutionalising Gossip: Stories from the Street}

In the introduction of his Kalimat al-shu'arā, Mirza Afzal Sarkhush clearly points out that "hagiographic" scope of poetic tazkiras I referred to earlier. Indeed, he goes so far as to place poets immediately after the prophets and to intimate that reading about the lives of the poets will be of spiritual use for the audience:

The relation between the munificent poets and the prophets-peace be upon them-is one of extreme closeness. As a matter of fact, both these groups of people are in constant touch with the primary source of graces (mabda'-i fayyāż) and the hidden world ('ālam-i ghayb). Mulla Nizami has written:

Among great people, a group came in the first row, and the other in the second: the first row is that of prophets, and the second is that of the poets.

There should be no doubt, then, that remembering the lives and listening to the utterings of such elevated natures will not be devoid of general gains and of sure benefits. ${ }^{14}$

Not all the individuals described in Indo-Persian tazkiras of the late Mughal period, however, fit comfortably into this elite group of "elevated natures". Nor does the way their lives are presented always point in the direction of spiritual exempla. As a matter of fact, some notices come, so to speak, directly from the streets-the second axis of this chapter-and hint at the interaction within poetic maktabs of individuals apparently well beyond the pale of hagiographic canons, and sometimes also of the social spaces traditionally connected to Persian literature in South Asia, as in earlier periods. It is the case, for instance, of an individual mentioned in the Safina-yi Hindī who is simply called "Pinki", the Hindi term for an opium addict, a term that subsumes his poetic persona:

He belongs to the common people of Delhi (az ahāli-yi Dihlī ast). Since he was addicted to opium, he chose this Hindi word as his own poetic

14 Lacchmi Narayan Shafiq, Tazkira-yi gul-i ra'nā, p. 2. The long pre-codification of the sufi and generally 'irfān̄ "gnostic" concepts in the language of Persian poetry (well scrutinised by J.T.P. de Bruijn, Persian Sufi Poetry: An Introduction to the Mystical Use of Classical Poems (London: Curzon, 1997)) allowed a non-contrastive overlap of the poets with saints. 
name. He wrote a masnavi describing opium and was still alive in the age of Muhammad Shah.

The one who gave opium to Pinki

left the tress of Layla in the hand of Majnun.

He is a drunkard, a libertine, a shameless man

$H e^{\prime}$ s not even Pinki, he's opium, nothing else. ${ }^{15}$

Bhagvan Das's tazkira mentions other authors of Persian poetry who were addicted to drugs. ${ }^{16}$ One was an Iranian named Muhammad Hasrat, whose social background was very different from that of Pinki:

He was a Sayyid from holy Mashhad. He was warm-hearted and had a good nature and had inherited the title of guardian of the sacred mausoleum of Imam Riza. He was strongly addicted to opium, and because of this he died at the beginning of the reign of Muhammad Shah. ${ }^{17}$

The poetic activity of Pinki and Hasrat appears to be little more than a pretext for textualising the pre-textual. What emerges here is in fact the will to show the strength of the gossip network immediately available to the tazkira writer, and to which he himself contributes. While remembering Pinki, about whom we know nothing else, Bhagvan Das conveys to the reader both a glimpse of non-courtly life in Delhi

15 Bhagvan Das Hindi, Safina-yi Hindī, ed. by S. Shah Md. Ataur Rahman (Patna: Institute of Post Graduate Studies and Research in Arabic and Persian, 1958), pp. 37-38.

16 The poets' taste for intoxicants is a common topos in tazkira tellings, touching even the most prominent "model" authors of the Safavid-Mughal age such as Sa'ib-i Tabrizi and Bedil; for Sa'ib's well known inclination towards wine and opium see, for instance, A.H. Zarrinkub, Zā' $i r-i$ Hind, in M.R. Daryagasht, $S \bar{a}^{\prime} i b$ va sabk-i hindī (Tehran: Nashr-i Qatra, 1992), pp. 75-83, p. 80; as far as Bedil is concerned, see Bindraban Das Khwushgu, Safina-yi Khwushgū, ed. by S. Shah Md. Ataur Rahman (Patna: Institute of Post Graduate Studies and Research in Arabic and Persian, 1959), p. 109. The motif of debauchery among poets, while narrativising social and economic trends (see, for instance, Rudi Matthee, The Pursuit of Pleasure: Drugs and Stimulants in Iranian History (Princeton: Princeton University Press, 2009), pp. 46, 105-08), is perfectly inscribed within the ultra-classical malamati mode of Persian suficate poetry (i.e. the quest for the blame of the prudes); not surprisingly, immoral and addicted poets are often the protagonists of late conversions (in Khwushgu's description, Bedil himself is said to have completely quit intoxicants at a certain point in his life), following a bioliterary scheme that can be traced back to the figure of the early Ghaznavid master Hakim Sana'i reconstructed in Timurid works such as Dawlatshah Samarqandi's Tazkkirat al-shu'arā and Jami's Nafahāt al-uns; see J.T.P. de Bruijn, Of Piety and Poetry: The Interaction of Religion and Literature in the Life and Works of Hakim Sana''i of Ghazna (Leiden: Brill, 1983); and R. Zipoli, “The Obscene Sanâ'1̂”, Persica 17 (2001), 173-94. Bhagvan Das Hindi (1958), p. 60. 
and a literary identity based on an ordinary/everyday practice of urban decadence but expressed through the choice of the poetic name (takhallus) and the comparison between opium and the tress of Layla. As far as Hasrat is concerned, we do not even know from Bhagvan Das what kind of relations the poet had with North India, if any: the apparent contrast between the religious affiliation of the poet with the shrine of Imam Riza in Mashhad and his ill-fated taste for intoxicants is enough to justify his presence in the tazkira. Both biographical notes lead us to question if and to what extent such observations mirror the subjects of everyday chats within poetic maktabs. The Safinna-yi khwushgu offers further examples, such as the curious details about the death of Ma'niyab Khan, in which an immediate taste for savoury gossip seems to go well beyond the poetic sphere:

Ma'niyab Khan passed away while he was having sexual intercourse, most probably because he used to eat very little food. God be praised, what an enjoyable way of dying! This is, in any case, quite an uncanny circumstance, which took place in the year 1157 [1744-1745].

Compare it with the note in the Safina-yi Hindī on Muhammad Ja'far, whom Bhagvan Das calls an "occasional poet" from Tehran who never went to India. More than in his poetry, however, the tazkira writer is interested in providing readers with the curious details of his death:

One night a Sayyid, one of the guardians of the sacred precints of Imam Riza, dreamt that the Imam said to him, "We keep Mir Ja'far very close to ourselves". That person told this fact to everyone the next morning, and three days later the aforesaid Mir passed away. ${ }^{18}$

More significant to us than the binding grace conceded to Mir Ja'far by the imam is the introductory caption "naql" that immediately precedes the passage. A common Arabic loanword, the verbal noun naql (alone or in related constructions with the copula such as naql-ast or the derived manqūl-ast) carries the idea of transporting something from one place to another and in Persian textual culture it is technically employed to indicate the act of relating (as well writing down) other people's words, as well as to street performance practices. Steingass's Persian dictionary suggests "telling" among the English terms for naql, and this seems quite an appropriate rendering here: the caption declaredly introduces 
a telling, a "story" related to the tazkira writer by an unnamed source and hinting explictly at the coeval lore of Persian poetic maktabs. Similar observations apply to another spectacular death, that of Jugal Kishor Sarvat, which returns us from the Shi'a shrines of Khorasan to the courtly social space of eighteenth-century North India:

He [Sarvat] was famous for his familiarity with subtleties, his witty speech, and his taste for good living and good company. He lived close to the court of Muhammad Shah, as a member of the deputation of the governor of Bengal, and the emperor got so affectionate to him that he became the object of the envy among the notables of Shahjahanabad. He spent an enormous sum of money for his son's wedding, thus attracting gossip. After the sack of Delhi he moved to Lucknow, and got in close contact with Nawab Shuja' al-Dawla Bahadur, who honoured him highly; eventually he moved to Farrukhabad. It is related that he was killed by his own elephant while he was mounting it. ${ }^{19}$

Again, the details about the pitiful death (preceded by the description of an equally "spectacular" career) of the gossiped-about socialite are introduced by a formula, "guyand" (literally "they say"), which is technically analogous to naql(-ast) and points to the oral diffusion of this story within the circles of Persianate intellectuals. The source is once again unnamed, but this is not always the rule and gossip is not the only basis for social storytelling in tazkiras. The identity of the informants is in fact often specified. While almost purely fictional personas (as far as their role in tazkira literature is concerned) like Pinki, Muhammad Hasrat, Mir Ja'far, and Jugal Kishor are more or less identifiable with the tellings about them, stories about more influential authors often come with authorising transmitters, as in the following brief passage by Bindraban Das Khwushgu about the great Delhi master Nasir 'Ali Sirhindi (1638-1696):

He generally had rough manners with people, in fact he even used to insult them. The honourable Shah Gulshan reports that once an old acquaintance of his went to visit him, accompanied by a boy. [Nasir 'Ali] looked at the handsome youth and said: "Is there a way for me to bite your lips?". His guest got offended and left. The day after [Nasir 'Ali] apologised sending him a line by Mirza Sa'ib. ${ }^{20}$

19 Ibid., p. 47.

20 Khwushgu (1959), p. 2, emphasis added. 
Shah Gulshan (d.1727), a prominent sufi and Persian poet based in Delhi, was a good friend of both Nasir 'Ali Sirhindi and of Khwushgu, the author of the tazkira. Predictably enough, poets talk about fellow poets, and the sources for the textualisation of oral gossip in tazkira literature are mostly about the poets themselves. In this specific case, the lessthan-saintly account is used to cast aspersions on the main rival of Bindraban's idol Mirza Bedil.

Again predictably, the apparently "extra-poetic" accounts above notwithstanding, a great number of reported stories and repartees deal with the production, reception, and criticism of poetry, including the occasions for composing "poetic responses" (jawabs) and for public readings, with authoritative masters offering critical evaluations and corrections (islah). Thus the telling also becomes a strategy that configures orality as a site for experimentation-a performative "place to try" - and where tensions between writers can be located, as in this rather comic episode regarding the Mughal poet Shayda and narrated by Mirza Afzal Sarkhush:

It is related that one day [Hakim Haziq] recited this matla ${ }^{21}$ in the presence of Mulla Shayda:

The nightingale abandons the rose garden if he sees me in the meadow.

Nobody will be left to worship the idols, if the Brahmin looks at me.

Shayda said: "It is clear that you composed this line feeling like an effeminate young boy!". Hakim [Haziq] got enraged and ended up throwing Shayda in the courtyard pond..$^{22}$

Such anecdotes, of course, are not specific to the literary environment of late Mughal Persian literary circles, be they courtly or non-courtly. In fact, contrasts between poets are a common topos in tazkira literature, and we can read the frequent recourse to such anecdotes by late Mughal biographers more cautiously as the diligent application of a generic protocol, rather than as the revolutionary desire to talk about real and local events. This is true also in the not uncommon cases where obscene vernacularity is employed, as in the following episode retold by Khwushgu:

21 The first line of a ghazal that gives the rhyming pattern to the whole poem.

22 Sarkhwush (1951), p. 51. 
It is related that one day Miyan Muhammad Sadiq Ilqa, who had a fierce rivalry with him [Sarkhwush] in musha'iras, went to visit him. Sarkhwush had a very long white beard, and pointing at it Ilqa said: "You are a poet, such a big beard does not suit you at all!". Sarkhwush replied: "People who have seen me have an image of me with this beard, and if I change they won't recognise me. But it is clear that you are very annoyed by beards, and, indeed, even that light down looks stranger to your face: you should keep it shorter than the fuzz on the testicles of wanton men!"23

Satire and obscene discourse (hajw $u$ hazl) are among the oldest modes of Persian literature, and tazkiras, just like dictionaries, are where they are traditionally recorded. ${ }^{24}$ To stay with this particular story, we can also note that the beard (with its hygenic and sexual connotations) is among the preferred targets of the genre, and we can even find verse specimens built on the same ungenerous comparison Sarkhwush made to put down his rival's criticism. ${ }^{25}$ Generic protocols can of course be profitably employed to talk about the real and the local, and late Mughal tazkira writers do speak about the present reality of poetic circles through relevant tellings, keeping respectfully within canonical requirements. Consider the following story about Mirza Bedil and Ja'far Zatalli, narrated in the Safīna-yi Khwushgü:

He [Bedil] had a very dignified nature. One night Ja'far Zatalli, who was one of the authors of satirical and obscene verse of the age (ki yaki az hajwiyān u fuhshgūūann-i 'aṣr būd), brought to him a masnavi which he had written in his praise. As soon as he recited the first hemistich, "I don't give a shit about 'Urfi and Fayzi compared to you! (chi 'Urfi chi Fayzi ba pish-i tu phish)", Bedil said: "You were very kind to come, but we, the poor Bedil, are not pleased listening to such stories regarding the great masters". He took two ashrafis from his purse and gave them to him, as a payment for the praise, thus silencing him. No matter how much those present-and especially the poor Khwushgu-insisted on letting Zatalli

23 Khwushgu (1959), p. 74.

24 See Riccardo Zipoli, 'Oscenità poetiche neopersiane: due tarjī'-band sulla masturbazione', Annali di Ca' Foscari 33 (Serie orientale 25, 1994), 258-59; and 'Elementi osceni nella lessicografia neopersiana', Annali di Ca' Foscari 35 (1996), 249-89.

25 Consider for instance the following line attributed to Munjik-i Tirmizi (tenth century) and recorded as an explanatory verse for the word ramgann in Asadi Tusi's Lughat- $i$ Furs (eleventh century): "rūy-at ba zīr-i rīshak andar nāpaydā/chūn kīr-i mard-i ghancha ba ramgān bar" (Your face disappears under a small beard/like the cock of a catamite under his pubic hair); Asadi Tusi, Lughat-i Furs, ed. by M. Dabbirsiyaqi (Tehran: Tahuri, 1336/1957), p. 146. The line is quoted in Zipoli (1006), 269. 
complete the couplet and thus listen to which word he had chosen to rhyme with phish, Bedil refused to do so. ${ }^{26}$

The reconstruction of a verbal exchange, part of a series of stories Khwushgu collected in order to show Bedil's character in poetic interactions, works well not only to communicate the contrast between poets of different status but also to convey a certain view (that of the tazkira-writer and of his circle) of the etiquette that ought to govern this specific socio-poetic space: the first-hand account of Bedil's declared respect for the masters of the Mughal past functions as a source of authority for Khwushgu, who can employ his well-informed gossip to build an immediately credible and influential lore. After all, the main audience of the tazkiras was made up of literati themselves, and access to the pre-textual orality of poetic circles, be it direct or mediated through the naql, provided the tazkira writer with an advantageous position to substantiate a more or less open prescriptive approach. In other words, the "minutiae of local detail" in the telling-oriented structure of the tazkira, be they Pinki's taste for opium or Bedil's dislike of satirical poems, became a powerful tool in the hands of the gossiper-biographer, who used them to express moral, social, and aesthetic judgements regarding the present time of poetic circles.

\section{Localisation: Pre-texts, Projections, and Protocols}

We are also left, like Bindraban Das Khwushgu and the other participants in the majlis held in Bedil's house, with the desire to know which word Zatalli chose to rhyme with phish. Phish is a colloquial Hindi expression of disdain, and its presence in Zatalli's only utterance in the exchange between him and Bedil directs our attention towards the role of the narrativisation of everyday life and orality in charting a selected view of the specific spaces and cultures surrounding the production of the text.

Outside Bedil's familiar house, but not too far from it, the market is, among the urban spaces of North India, a favourite setting in which to place Persian poets, as in the following story narrated by Khwushgu, with regard once again to Nasir 'Ali Sirhindi:

26 Khwushgu (1959), p. 113. 
Bhagwant Rai, known by the pen-name Qalandar, the son-in-law of Rai Chandar Bhan Barahman, the famous munshi, was a friend of his [i.e. Nasir 'Ali's]. He [Bhagwant Rai] told me this story about him: "One day we were sitting together, with a third person, on a rath, which is a means of transport, and we were passing through the Delhi bazaar. We saw a vegetable-seller who was having an argument with his beautiful wife, yelling every possible insult at her. Suddenly Miyan Nasir 'Ali got off the rath and we thought that he wanted to act as a judge to the fighting couple. After flattering the vegetable-seller with every sort of adulation and false words, he said: "To treat this gracious and fairy-like creature as if she were a horse or a donkey is indeed an inhuman and ignoble behaviour! I am a good person and I have done you no harm: If you are tired of her, please give her to me!" The vegetable-seller and all the other passers-by were struck by the brilliance of his words and the quarrel ended in the twinkling of an eye. ${ }^{27}$

It would be naive to simply take such a narrative at face value. The people of the market are in fact the main protagonists of the classic poetic genre known as shahr-ashub, in which the "beauties" of the city are described through their daily activities. ${ }^{28}$ The beautiful wife of the fruit-seller is thus not only an aspect of local colour but a literary character in no trivial sense, as the readers of the tazkira would have recognised. Thanks to the semantic power of a telling related by an eye-witness, Nasir 'Ali thereby becomes a literary persona himself, somehow acting, and codified, in the textual world he and the readers were familiar with. Analogous remarks can be made about other narrative topoi lying behind the tellings within the textualised world of Persian poetic circles shown in the tazkiras, such as the "madness" of poets:

[Maulvi Muhammad Hikmat] was an erudite and skilful man from Jaunpur. When he was thirty he went completely mad. One day he was running through the market in his delirium and some children started throwing rocks at him. He was saved by an acquaintance who took him away and managed to calm him down. He immediately composed this verse:

My head has become a field of poppies thanks to the childrens' stones: madness is blossoming, the season of spring has finally come ${ }^{12}$

27 Ibid., p. 3.

28 See Sunil Sharma, 'The City of Beauties in the Indo-Persian Poetic Landscape', Comparative Studies of South Asia, Africa and the Middle East 24.2 (2004), 73-81.

29 Hindi (1958), p. 63. 
In this anecdote, found in the Safina-yi Hindī, the subject of the story and the performance of the public composition and recitation of a verse explicitly coincide with the recognition, by the pretended "mad" poet, of the transformation of his own "real" condition of mental insanity into a textual paradigm, which even an occasional amateur of Persianate literary cultures would have identified with the lover Majnun. The madness of the poet in the Jaunpur bazaar, just like Nasir 'Ali Sirhindi's scene with the vegetable sellers in the market of Delhi, while retelling realistic glimpses of local daily life through oral gossip, transfers them onto the plane of literary codes. Such strategies, while calling upon the imaginary dimension of the characters and topoi of the poetic hyperspace, stretch them by adding to them the immediate socio-historical "reality". Thus the world of poetic imagination-the shahr-ashub, Majnun-is euhemerised, i.e. tranferred into the immediate historical, specific present. In Khwushgu's tazkira, for instance, we see Shah Yaqin actually composing his poems while sitting in the Delhi bazaar, as if on the literary stage of the shahr-ashub:

Most of the times he used to sit in the coffee-shop of Chandni Chawk in Shahjahanabad with his good friends, where he was always prone to read and recite poetry and to exercise his ability in composing it. ${ }^{30}$

The locus where the poet produces his craft is the same space in which Nasir 'Ali talks to the vegetable-seller and his beautiful wife, or where another madman, Shah-i Kabuli, dances and recites initiatic lines following Mirza Bedil's horse, according to the latter's autobiography. ${ }^{31}$

The everyday urban setting is also the place where poets/characters meet, in the biographic tellings, other characters / artists (who are, again, often the object of shahr-ashub poetry), such as painters and singers: a relatively well-known case is that of the story of the painter Anup Chhatr and the portrait he made of Mirza Bedil. ${ }^{32}$ Some of these characters even become the subjects of independent notices in tazkiras, as in the case of the female dancer Babri Rindi:

30 Khwushgu (1959), p. 259.

31 Mirza 'Abd al-Qadir Bedil, Kulliyāt, ed. by K. Khalili (Kabul: da Pahane wizarat, da Dar al-ta'lif riyasat, 1344/1965-66), Vol. 4, p. 169.

32 Ibid., pp. 281-85. The episode has been described in Abdul Ghani, Life and Works of Abdul Qadir Bedil (Lahore: Publishers United, 1960), pp. 67-68 and briefly discussed in Pellò, 'Il ritratto e il suo doppio nel mașnaw̄i indo-persiano di Nāṣir 'Alī Sirhindī', in La mandorla e il mirabolano: esotismi, contaminazioni, pittura e Oriente, ed. by R. Favaro (Venice: Cafoscarina, 2007), pp. 111-13. 
The people of the street used to call her bhori [innocent, silly], she was one of the dancers of Shahjahanabad. She left her shameful living and her nature was very agreeable. She had no equals in singing (naghmasara $\bar{a}^{\prime} \bar{\imath}$ ) and dancing (raqs). She used to meet Mirza Bedil frequently, and she composed poetry. ${ }^{33}$

As with Pinki above, the interplay between the real and the imaginary allows the tazkira writer to textualise a "marginal" character within the same space as the great masters: ${ }^{34}$ Babri Rindi, just like the others, is a real character who embodies a literary character, who then becomes in Bhagvan Das's tazkira a fictive character who talks about reality, calling upon the authoritative weight of Bedil's poetic circle and projecting the whole process (and its reverse) onto it. In fact, Bindraban Das Khwushgu, closely related to Bedil's circle, calls upon the same cast of characters and places himself on the shahr-ashub stage while telling an autobiographical story about his own ill-fated love for a female dancer:

When I fell in love with a female dancer, and was extremely distressed because of it, one day I happened to be in his [Shah Gulshan's] presence [at Zinat al-Nisa' mosque]. I couldn't help bursting into tears, and he asked me what was going on. I told him everything and said, "Can you tell me if will finally succeed in having her?". He replied: "I will divine it in my dreams". When he woke up, he said: "You won't have her, in fact I have even seen the person who is entitled to have her. He has the looks of a Kunwar and seems to be a chieftain". I felt desperate. After a few months she was bought for one thousand five hundred rupees by the representative of the zamindar of Bikaner, who took that beauty to his province. $^{35}$

Just as important as the poets' house and the street of the bazaar, the temple milieu (masjid, dargah, takiya, etc.) is another main locus for constructing (and remembering) the lore of Indo-Persian poetic circles in tazkira tellings, a kind of screen on which we can watch textualised orality at play. The narrative objects of the tazkiras, i.e. the poets, are themselves in several cases represented as sufis, renunciates, faqirs, and generic holy men, and it is surely redundant to recall that these personas form a substantial part of the Persian literary cast as whole.

33 Hindi (1958), p. 90.

34 The presence of the well-known conversion topos is a further hint in this direction, see footnote 17 above.

35 Khwushgu (1959), p. 167. 
Along the same lines of the examples above, the recovery of the pretextual and localised orality that is textualised in tazkira tellings charts a productive interplay between real(istic), fictional, and imaginary planes. An exemplary story is narrated by Khwushgu about the Naqshbandi shaykh and musician Shah Gulshan, who has already appeared, and whom the Safina describe as the "Amir Khusrau of the times", according to the definition of "most of the accomplished singers", and as living in poverty ("he lived on the khichhri of the offerings"), at the mosque of Zinat al-Nisa on the banks of the Yamuna in Delhi. Khwushgu, who boasts about having been in close contact with him, tells us that:

One day he was travelling back from Lahore and was crossing a perilous desert with very rough terrain, with sharp thorns that were tormenting the travellers' feet. In the middle of the stage (manzil), he felt the urge to compose poetry. He saw the shade of a tree and left the caravan. In that unusual place he started thinking of a ghazal. A faqir, completely naked, appeared out of nowhere and, being extremely surprised, asked him, “O darvish, how can you stop here, in this path where even lion-hearted men feel anguish? Get up and continue your walk, otherwise you will die!" He replied "Thanks to the grace of my weakness, I got so estranged from myself that the idea of going back is a danger itself. This ink-holder, this pen, this paper and this torn cloak, is all that remains of me: if the end of my life comes now it would be a blessing". [...] He did not leave that place until he had finished his ghazal. ${ }^{36}$

The travellers' misery, the bush thorns on a desert road, the asperity of the stages of the journey, and so on, are all canonical metaphors for the harshness of the spiritual path in Persian and Persianate literatures. Thus the tazkira notice sets up a double mirror between experience, fictional narrative, and poetic text: it does not include Shah Gulshan's ghazal but the terms it uses to describe the occasion in which the ghazal was composed are common in the ghazal code, thus raising the question of whether this particular ghazal by Shah Gulshan used those terms too. This telling places the sufi poet on the stage of his own craft, adds tridimensionality to this specific theme of suficate poetry, and locates a timeless and placeless literary image in a precise time and place. This manner of bringing the theme to life is comparable to the visual comment of a miniature painting illustrating a ghazal. But unlike miniature painting, such a telling also relocates the poetic event to a 
specific historical present, one shared by the characters of the tazkira and its immediate readers - it gives the event visible movement and an audible voice.

Similar observations can be made for the following story, this time located in a Hindu temple, regarding the sufi poet and tazkira writer Muhammad Afzal Sarkhwush:

While he was coming back from Ajmer he stopped at Manoharpur and ended up entering the shrine where a Hindu ascetic (hind $\bar{u}$ faqīr) lived. He enjoyed the conversation that ensued so much that he remained there for twenty-five days, no matter how much his travel companions insisted on departing. A brilliant point in that conversation occurred when that monotheist ascetic (faqi $r-i$ muwahhid) said during the discussions: "Idolatry and Islam are one and the same thing!". Sarkhwush replied: "If things are like this, then why don't you become a Muslim?". The faqir replied: "Things are exactly like this! So why don't you become a Hindu (chirā hind $\bar{u}$ namishavī)? One side is equivalent to the other, and my point is that sometimes it is necessary to go beyond both". The faqir then recited this lines from [Rumi's] Mas navĩ:

When the absence of colour ${ }^{37}$ becomes the prisoner of colour, then a Moses starts a war against another Moses.

When you reach the colourlessness which used to be yours, then Moses and the Pharaoh will make a durable peace.

And if you still have questions about this subject

then you should know that colour always matches with vain debates. ${ }^{38}$

In this particular episode, the memorialisation of orality in the telling can also be read as a strategy. Thus the classical theme in Persian suficate poetry of the supreme unity of idolatry and Islam and the recognizable poetic character of the non-Muslim Holy Man make visible and audible space for "new" emerging subjects in the socio-textual realm of IndoPersian literary culture. The Vaishnava tazkira writer is speaking about

37 The text has the form بيرنكئن instead of the expected بيرنى "colourlessness", which is found in Nicholson's edition of Rumi's Masnavī; see The Mathnawí of Jalálu'ddín Rúmí, Edited from the Oldest Manuscripts Available, with Critical Notes, Translation and Commentary, ed. by R.A. Nicholson (London: Luzac \& Co., 1925), Vol. 1, p. 152 (vv. 2467-69). I consider نيرنكي, which can also be read as nayrangī "magic", a misprint and follow the text established by Nicholson in my translation.

Khwushgu (1959), p. 73. 
himself (and the social groups he represents) and the canon of Persian poetical culture as well as about the "historicity" of Sarkhwush and his meeting with the "Hindu faqir", along the lines I have repeatedly dealt with elsewhere. ${ }^{39}$ The ascetic is even made to substantiate his brilliant reply with an impromtu recitation of three famous Persian lines from the first daftar of Jalal al-Din Rumi's Mas navī-yi ma'navī, containing the much-codified imagery of Moses and the Pharaoh, thus locating the ascetic well within the protocol frame of Persian poetic tazkira. Moreover, to remain within the intertextual world of Khwushgu's circle, the whole episode can be read in parallel with the telling about the dialogue between his master Bedil and his Brahmin fellow-traveller, a scene retold in the Chahār 'Unșur, where, conversely, Bedil wins an argument regarding the nature of time (and converts the Brahmin to Islam) by technically referring to the whole duration of the life of Brahma as "the twinkling of the eye of Vishnu the black". ${ }^{40}$

Finally, tellings from the "temple" environment like those from other settings, especially the bazaar, can also function as containers to hint at vernacular practices and identities. This is the case in the first-hand account of a meeting between Khwushgu and the Kashmiri sufi 'Abd al-'Ali Tahsin, "who used to stay with Saint Gulshan at the Begam's [Zinat al-Nisa'] mosque":

One day he was sitting on the banks of a stream, in the shrine of a darvish, with two or three friends. With a cup full of bhang in his hand, he was talking about it: "Some friends describe bhang with the word raini, and Indians call the night "rain". Is it because the color of bhang resembles that of the night, or is rain used to allude to earth, since whoever takes bhang is brought down to the earth?" I arrived during this conversation and listened to it. He saw me, and after the greetings I said: "O master, the word raini is a term used by Indian dyers and indicates the vats where they keep colours, especially the colour red, and in which they immerse clothes to dye them. This is the clear similitude between rain and bhang: if you immerse yourself in it, it makes you colourful!". Tahsin offered the cup to me and said: "Since you are a Hindu, this is your job!"41

39 See Pellò (2014a), and 'Between Gayā and Karbalā: The Textual Identification of Persian Hindu Poets from Lucknow in Bhagwān Dās Hindī's Tazkira', in Religious Interactions in Mughal India, ed. by V. Dalmia and M. Faruqi (New Delhi: Oxford University Press, 2014b).

40 Bedil (1965-66), pp. 41-45.

41 Khwushgu (1959), pp. 266-67. 
The telling gives Khwushgu the opportunity to promote himself as an authority as far as Hindi and "Indian" vernacular cultures are concerned, somehow expanding the well-experimented strategy of using tazkiras as instruments for including details about the specific cultic space of non-Muslim Persian writers in North India in late Mughal times. Along the same lines, the explicit recognition of Khwushgu's religious identity through Tahsin's persona (and the implicit reference to the ritual use of hemp by sadhus and the like) hints at the emergence of the socio-semiotic identity of Vaishnava authors within Indo-Persian poetic circles that I have discussed elsewhere. ${ }^{42}$ Equally relevant to our investigation is the philological discussion at the centre of the story. Along with dictionaries and commentaries, tazkiras are where the correct meanings and uses of words are discussed, especially those relating to the poetic world, predictably enough. A large part of the discussions taking place during musha'iras, majlises, and sessions of poem-correction represented in the tazkiras deal, in fact, with the etymology, meanings, and metaphorical value of a specific word, and the correct opportunity to use it. Khwushgu places this communicative dynamic in public places such as the streets and mosques of Delhi and matches the subject of the discussion with the place of the story. The use of bhang by fellow poets and the vernacular world adumbrated behind it are thus included in the tazkira narrative through the frame of a philological discussion, which follows the scheme even to its conclusion, with a well-earned prize given to the author of the most brilliant definition.

\section{Conclusion: The Langue and the Parole of the Maktab}

The relatively large colloquial Hindi vocabulary found in tazkira stories about the everyday life of Indo-Persian poets should not go unnoticed. Pinki ("intoxication"), rath ("cart"), bhori ("naive woman"), phish ("pshaw!"), khichhri (the well known rice dish), bhang ("hemp drink"), and rain/raini ("night/nocturnal"), the words mentioned in the short excerpts analysed here, are just a few examples from a much larger catalogue of vernacular, everyday words that are very frequently accompanied by their Persian or Arabic-Persian equivalents-as if the

42 Pellò (2014a). 
readers would not know. ${ }^{43}$ However, Hindi is not spoken within the tellings:

Once he [Mirza Bedil] went out with a stout hand-stick (chīb-i dastī), which in Hindi is called "lath", and met a great shaykh who had had the grace of being a close acquaintance and companion of his for thirty years. [The shaykh] said something about the stick ('așa $)$, and the honourable Bedil immediately replied with five elegant and rhymed definitions: "sunnat al-anbiyā" (the tradition of the prophets), "zinnat al-șulah" $\bar{a}$ " (the ornament of the pious ones), " $m u^{\prime} n \bar{\imath} s$ al-a' $m \bar{a}$ " (the companion of the

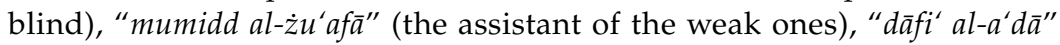
(defense of the enemies). ${ }^{44}$

Bedil ventures into the unsafe streets of Delhi with a "lath", but talks to his friend the shaykh about an 'așa, improvising five Arabic metaphors for it: Hindi is alluded to, but the official spoken language of the telling is Perso-Arabic. As a matter of fact, notwithstanding the insistence on mentioning and explaining Hindi terms within the Persian texture of the narrations, not much room is left for Hindi in these stories, not even when the poet-actors deal with the small-talk of the maktab gossip, the street environment of the bazaar, or the vernacular world of sadhus and faqirs. The absolute star of Khwushgu's tazkira, Mirza Bedil, is quite clear on this matter in his own autobiography. When retelling his meetings with one of his masters, the wandering ascetic Shah Muluk, who was living in Banaras, "stretched out under a tree like a shadow, like grass woven in a clot of earth", ${ }^{45}$ Bedil writes:

In those days he composed almost forty lines, and they became the precious substance of the awakening of the ignorant author of these pages [...] Since most of them were composed according to the expressions of India and followed the rules of Rekhta, it would have been inappropriate to include them in the present book, which is obedient to the rank of Persian.

How many concepts that, due to the strangeness of language, with all their petulance remained on the pages of secrecy! ${ }^{146}$

43 I have discussed the implications of this strategy of vernacular inclusion with Persian glosses "as if readers did not know" in my 'Local Lexis? Provincializing Persian in Fifteenth-century North India', in After Timur Left: Culture and Circulation in FifteenthCentury North India, ed. by F. Orsini and S. Sheikh (New Delhi: Oxford University Press, 2014).

44 Khwushgu (1959), p. 120.

45 Bedil (1965-66), p. 20.

46 Ibid., p. 34, emphasis added. 
The vernacular utterings of Shah Muluk are not allowed into the Persian frame of Bedil's Chahār 'unșūr, just as the Hindi street conversation about the lath between Bedil and the shaykh does not fit the generic protocols of Khwushgu's Safina and must be filtered through the Perso-Arabic linguistic and poetic code (i.e. the five rhymed definitions) to properly work within the palimpsest of the tazkira. Thus, direct speech is not only represented in Persian (think, for instance, of Nasir 'Ali's exchange with the vegetable seller in the Delhi market) but can just as often be substituted by Persian verse, as in the above case of the "Hindu faqir" talking to Muhammad Afzal Sarkhwush in the shrine at Manoharpur.

It would be trivialising to read this as a straightforward strategy of exclusion. The parole of Indo-Persian poetic circles cannot be represented as such within the textual space of the tazkira but can-and must-be invoked through its projection onto the langue of Persian poetic culture. Vernacularity is not absent but hidden and works like a sub-text, continuously evoked by "subtitled" Hindi vocabulary and the oral realm of the localised tellings and gossip, once again "dubbed" in Persian. In more general terms we should keep in mind that tazkiras, these "hagiographies of (poetic) language", ${ }^{47}$ are written in the attempt to capture not the elusive, unattainable "real" life of the literati but rather their textual existence. Nevertheless, the marked historicity of the biographical tellings is summoned through the use of expressive rules that are expandable, if not changeable. Giorgio Vasari, in his Vite de' più eccellenti pittori, projected the everyday life stories of Italian artists (who incidentally are all made to speak literary Tuscan and not their Venetian or Lombard dialects) onto the aesthetic screen of Renaissance figurative art, yet at the same time textualised the vernacular spaces of sixteenth-century Italy surrounding it, as in the tragicomic story of the beautiful young porter whom the Marquise of Mantova manhandled so as to make him a better model for Saint Sebastian's martyrdom. ${ }^{48}$ In a

47 Consider, for instance, the opening lines (immediately after the canonical eulogies) of the introduction of the Kalimāt al-shu'arā: "Word (sukhan) has no beginning and is eternal, because speech (kalām) is one of the seven attributes (sifät-i sab'a) of God. Since the essence has no beginning and is eternal, its attributes must consequently be eternal and with no beginning as well. Until the spring of the ability of speaking (nutq) will be flourishing, every tongue will be a flower seller of colourful expressions; and among the totality of mouths and tongues, the dignity of metered words and poetry will forever be superior to non-metered words and prose"; Sarkhwush (1951), p. 1.

48 The episode is found in the life of the Veronese painter Francesco Bonsignori (c.14601519); see Vasari (1880), 5, pp. 299-307. 
similar fashion, what I have called the lore of later Mughal Indo-Persian poetic circles, their web of tellings, was textualised and translated onto a regulated representational plane, yet at the same time the result of this process can be read as a telling itself, one that surveyed the pre-textual and the con-textual spaces of these poetic circles in order to shape a live, localised, and influential narrative of the specific world of Persian poetical production and reception in late Mughal North India. 